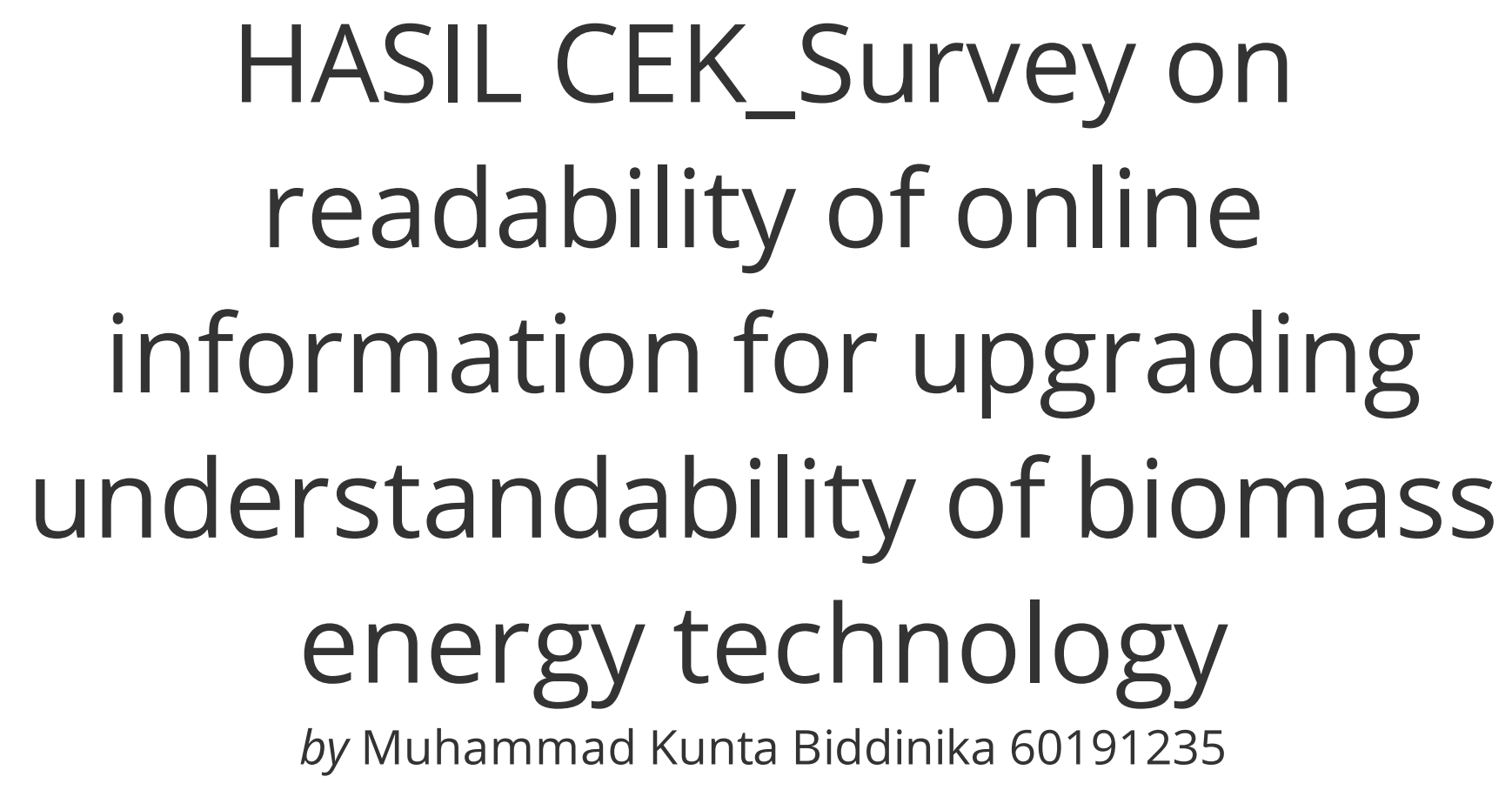

Submission date: 22-Nov-2021 08:46AM (UTC+0700)

Submission ID: 1709555156

File name: Survey_on_readability.pdf (705.78K)

Word count: 6172

Character count: 31486 


\title{
Survey on readability of online information for upgrading understandability of biomass energy technology
}

\author{
Muhammad Kunta Biddinika ${ }^{1}$ Ahmad Muhammad Diponegoro ${ }^{2}$. \\ Raden Muhammad $\mathrm{Ali}^{3} \cdot$ Raden Ibnu Rosyadi ${ }^{4}$ Koji Tokimatsu ${ }^{1}$. \\ Fumitake Takahashi ${ }^{1}$
}

Received: 19 May 2016/ Accepted: 30 January 2017

(C) Springer Japan 2017

\begin{abstract}
Waste management contributes to renewable energy such as biodiesel production from processes of various types of biomass including vegetable oils, animal fats, and waste of edible oil. Successful waste management effort is influenced by people concern about benefit of waste management including for renewable energy from biomass. It involves their understanding initiated by literacy on biomass energy. To help increase literacy on waste recycle and biomass energy technology, we study readability of online information regarding biomass energy in Indonesian language (Bahasa Indonesia). Indonesia is considered as one of biomass-rich country with a little utilization for energy. The readability is studied by combining two approaches: measurement by readability standard and survey on readability confirming measurement by the standard. This study focuses on the confirmation survey readability standard measured on biomass online information in Indonesian language. In the survey, 19 online text materials were read by respondents and they were asked to give their impression whether the texts are easy or difficult to understand. From this study, what factors influence understandability of text information are shown. The results could be
\end{abstract}

\footnotetext{
$\triangle$ 3. hammad Kunta Biddinika kunta.m.aa@m.titech.ac.jp; mkuntab@gmail.com

1 Tokyo Institute of Technology, 4259 Nagatsuta-cho, Midori, Yokohama, Kanagawa 226-8502, Japan

2 Faculty of Psychology, Universitas Ahmad Dahlan, Jalan Kapas 9, Semaki, Umbulharjo, Yogyakarta 55166, Indonesia

3 Faculty of Teacher Training and Education, Universitas Ahmad Dahlan, Jalan Pramuka 42, Sidikan, Umbulharjo, Yogyakarta 55161, Indonesia

4 Faculty of Geography, Universitas Gadjah Mada, Bulaksumur, Yogyakarta 55281, Indonesia
}

a guidance for preparing text information to raise people concern on waste recycle and renewable energy in general.

Keywords Internet - Indonesia - Biomass information . Readability $\cdot$ Understandability $\cdot$ Survey

\section{Introduction}

Waste management has become an important policy worldwide for sustainable human activities. It contributes not only for the minimization of serious environmental problem caused by waste but also for the future energy supply from renewable sources especially from biomass. Biomass constitutes most part of organic waste as shown by municipal solid waste (MSW) composition in Mexico, France, Netherlands, Australia, and in various cities in China as the world's largest waste generator [1]. Typical biomass waste is also largely generated from some palm oil industries, food industries, as well as biodiesel industry. Utilization of biomass waste for energy has been studied such as empty fruit bunch as a waste from commercial production of palm oil [2, 3], coconut shell and cocoa pod husk from large food and beverage industries [4-6], and Jatropha curcas solid waste from biodiesel industry [7].

Successful waste management effort could be influenced by people concern on the benefit of waste management including for renewable energy from biomass. The concern may be affected by understanding of the benefit of biomass energy and literacy of the information which in turn, smooth implementation of both waste management and biomass energy will be achieved.

In a study of waste disposal, recycling and composting in south-west Sweden, Sterner and Bartelings [8] highlighted earlier researches in which education, concern 
for the environment, knowledge are considered as important positive determinants of recycling, although they also found that not too many studies include many attitudinal variables. Some studies also indicate waste management still encounters challenge in the implementation which associates with both technical and non-technical barriers such as economic, social, cultural, and psychological factors which are often out of concern especially in developing countries $[9,10]$.

Indonesia, a developing country, is the fourth most populous country in the world as well as the third largest greenhouse gas emitter in the world. Indonesia is also one of the biomass rich countries; however, its utilization is still relatively low, especially for energy generation [11, 12].

The research presented in this paper is part of a larger study covering media readability for improving public understanding on renewable energy in Indonesia. This paper focuses only the findings and discussion relevant to the survey of readability confirming our readability measurement on biomass technology online information.

The rest of this paper is structured as follows. After this introduction of study, some previous study related to this research are presented in Theoretical background. Materials and methods explains questionnaire methodology used in this survey study. In addition, this section also briefly explains text information of biomass energy technology which is available online including how to obtain them. Results and discussion presents findings and lessons learned from questionnaire distribution. Finally, the Conclusions and recommendations are presented including implications of this study.

\section{Theoretical background}

Previous studies reported difficulties on implementation of waste management as well as renewable energy technology originated from low public awareness and understanding on renewable energy. An understanding gap on renewable marine energy information particularly between policy makers, investors, and the general public was observed in a study in Malaysia and has become a barrier to push the technology forward [13]. A similar study in India also revealed some barriers in the implementation of renewable energy which are related to its information, such as the lack of a formal information channel on renewable energy for small and medium-scale enterprises, poor access to renewable energy information compared with the access to conventional energy technologies, lack of easy access to information about the latest renewable energy technologies, and also the preference of general public to take their friend's advice rather than to obtain information from experts [14].
Biomass information in the Indonesian language (Bahasa Indonesia) may also be difficult to understand, which in turn, influences Indonesian people's knowledge on biomass 3 ergy. Regarding information source in Indonesia, since Indonesian people are among the largest internet users in the world and the number of Indonesian internet users has grown dramatically this decade as recorded by United Nation Development Program (UNDP) and World Bank [15, 16], internet also becomes the most accessed media surpassing television, newspaper, radio, tabloid, and 3hagazine [17]. Therefore, this paper presents a survey on readability of biomass energy information available in internet written in Indonesian language.

DuBay suggested in his comprehensive review on readability studies [18] that researchers on readability studies have recommended that due to the limitations of readability formulae, the formulae are best used in conjunction of with other methods. Basically, readability can be determined with using two methods: the readability formulae and reader responses [19].

This work mainly adopts a leading work of Harvey and Fleming in the selection of printed health promotion materials used by Environmental Health Departments in the UK [20]. They highlighted how effective environmental health promotion brochures in conveying the intended message to the target audience 1 The effectiveness was evaluated by two interlinked stages: a quantitative measure of the ease with which a written text is read by a standardized readability test and a measurement of target audience reaction to the promotion brochures. Some reactions were shown by the study such as the brochure was not well laid out, it was too much text on the pages, the text was too small, it could be understood by only a few customers, and so on. This reaction could improve the creation and selection of written environmental health promotion materials.

The similar-but more detailed-method which is also adopted by this study was done by Harvey et al. [21] in their attempt to examine printed health and safety leaflets effectivess in changing knowledge, attitudes, and behavior of smal1 or medium-sized enterprises' employers and employees in relation to health and safety of the workplace. Four steps of activities were carried out for the data collection of their study: (a) preliminary structured interviews to clarify the purpose of the leaflets; (b) readability measurement using three standard tests, Flesch Reading Ease score, Gunning's FOG Index, and Simple Measure of Gobbledygook (SMOG) formula; (c) structured interviews to gather opinions on some features of the le 1lets which influence effective communication, such as layout, typographical features, color, illustrations, langua 1 used, prevalence of phrases, and flow information; and (d) comprehension tests for each leaflet by requesting respondents to peruse the leaflet. 
In general, the aforementioned method is well known as rapid appraisal method [22]. The method combines four stages: (1) a preliminary survey by focus group discussion assessing acceptability and feasibility of a material or range of materials; (2) a readability test for finding which materials are considered as comprehensible to the target audience; (3) a survey by questionnaire for assessing materials' acceptability among target audience; and (4) making decision which materials will be used.

Based on the aforementioned studies, our paper makes three contributions on waste management and renewable energy. First, despite of its environmental friendliness, renewable energy technology still faces less satisfactory of public acceptance and participation. Hence, and perhaps most important, this study sparks and encourages study on public understanding leading to acceptance as well as participation toward waste management and renewable energy technology.

Second, while most of readability studies use approach of text measurement using standards, our study complement text measurement by readability standards with survey as a confirmation of text measurement. It would provide a better understanding of the utilization of readability standard on understandability prediction especially for written information.

Third, we collect original data from a significantly larger cross-section of communities as our respondents. No existing readability survey uses data with more than 100 respondents, since readability survey requires relatively high willingness of respondents.

\section{Materials and methods}

This survey employed 19 written information on biomass technology as the materials of the study. The materials were online information obtained using internet search engine accessed in the second and third weeks of October 2014 for the folld $3 \mathrm{ng}$ terms of Indonesian language (Bahasa Indonesia); biomass energy, biomass, renewable energy of biomass, and biomass power, respectively. The content of the text materials is briefly presented in Table 1 . However, we found that uniform resource locator (URL) where text number 18 located could not be accessed unexpectedly due to its removal by the website owner [23]. Sky Energy Indonesia, a joint venture which has been established in 2008 with Hitachi High Technologies Corporation Japan, chose to update its latest website to English version only. At the time of text selection from Google's search results, the URL where text number 18 is located was still available. It was an introduction as well as definition of renewable energy written in the Indonesian language. Recently, the text is only available in English in the new URL (http:// sky-energy.co.id/renewable-energy/) [23]. The Indonesian translation of the currently available text was exactly similar as the text of the material of this study.
Table 1 Brief content of each text material used for the questionnaire

\begin{tabular}{ll}
\hline Text No. & Content \\
\hline 1 & Utilization of biomass for energy [24] \\
2 & Definition of biomass energy and its examples [25] \\
3 & Definition of biomass and its utilization for energy generation [26] \\
4 & Definition of biomass and one example of biomass energy from food crops [27] \\
5 & History of biomass energy and reasons why it is urgently needed now [28] \\
6 & Definition of biomass energy [29] \\
7 & Biomass energy from organic wastes [30] \\
8 & Biomass as a potential renewable energy source in Indonesia [31] \\
9 & Conversion of biomass into energy [32] \\
10 & Potential of biomass energy in Indonesia and how to convert it [33] \\
11 & Biogas as an alternative energy from waste and biomass [34] \\
12 & Challenge to utilization of biomass energy [35] \\
13 & Cacao shell as biomass renewable energy source [36] \\
14 & Utilization of biomass gasification for energy source in boarding school [37] \\
15 & Definition of biomass as a renewable energy source [38] \\
16 & Benefit of biomass energy [39] \\
17 & Utilization of biomass energy to replace fossil energy [40] \\
18 & Definition of renewable energy [41] \\
19 & Definition of renewable energy [42] \\
\hline
\end{tabular}

Uniform resource locator (URL) of each text material is provided by the reference numbered within parentheses 
More detailed information of the text materials, including the process of obtaining the materials and readability measurement on the materials using the standard tools have been reported in our previous papers [23, 43] conducted prior to the survey.

Since there are 19 texts, it is a challenge to distribute text materials to respondents. Two options are available. First option, all respondent is requested to read all of text material, from Text No. 1 until Text No. 19 and to answer similar questions belong to each text subsequently. This option has advantage of less respondent required, shorter time for overall survey, and consequently less cost spent. By only, for example, 20 respondents, we could obtain 20 data of each text entirely. However, it affects less willingness of respondent to read the texts and to answer the questions afterwards. This option also requires longer time for each respondent to answer the whole questionnaire.

Second option, all respondents are requested to read only one text material and to answer the subsequent questions belong the text. This option has advantage of more willingness expected from respondents to read the text and to answer the question which in turn, more serious attention could also be expected from respondents to read the text and to answer the questions. It also requires the shortest time for each respondent to answer the whole questionnaire; however, the longest time is needed for overall survey. In comparison with the first option, for example, 20 respondents could only contribute 1 data of each text entirely and one of the text obtains 2 data. To acquire 20 data of each text, 380 respondents are needed consequently. This option is thus considered as the most costing a lot of money for this survey.

Therefore, we selected a middle way between the first and second options. All respondent is requested to read three out of 19 text materials which are categorized based on its length and to answer similar questions of each text subsequently. Compared with the second option, this third option requires not too long time for each respondent to carry out the whole questionnaire, so that it gives rise to more willingness for respondents, more serious attention, as well as relatively less costly. In comparison with the first and second options, 20 respondents contribute 3 data of each text entirely and three or four of the text obtain four data.
To arrange text materials into questionnaire sheet, we categorized text materials into six groups consisting of three and four texts, as shown in Table 2. Each text in a group represented various length of text; short, medium, and long, so that each respondent was assigned equally. The variety of text length was defined by the number of words contained within the text, as shown in Table 3.

As the respondent, we recruited university students with various education backgrounds in cooperation with several universities lecturers. Most of respondents were in the age between 15 and 20 years $(55.2 \%)$ and $21-25$ years (39.1\%). Their education background was mostly English Education (33.0\%), Economics (21.5\%), and Engineering (18.3\%). Tables 4 and 5 provide detailed information regarding the respondents.

The questionnaire was distributed to the respondents in the classroom of associated lecturers between October and December 2015. The respondents read and replied the

Table 3 Category of text materials publisher for the survey and length of materials [23]

\begin{tabular}{llc}
\hline Designated number & Category of material publisher & $\begin{array}{l}\text { Length of } \\
\text { material } \\
\text { (words) }\end{array}$ \\
\hline Text No. 1 & University & 1274 \\
Text No. 2 & Community & 418 \\
Text No. 3 & Community & 565 \\
Text No. 4 & Government agency & 337 \\
Text No. 5 & Individual & 1011 \\
Text No. 6 & Community & 259 \\
Text No. 7 & Community & 531 \\
Text No. 8 & Government agency & 549 \\
Text No. 9 & Government R \& D & 297 \\
Text No. 10 & Community & 1005 \\
Text No. 11 & Government R \& D & 211 \\
Text No. 12 & Community & 534 \\
Text No. 13 & Community & 869 \\
Text No. 14 & Community & 723 \\
Text No. 15 & Community & 447 \\
Text No. 16 & Community & 479 \\
Text No. 17 & Community & 973 \\
Text No. 18 & Business & 435 \\
Text No. 19 & Individual & 450 \\
\hline
\end{tabular}

Table 2 Questionnaire material groups based on text's length categorization

\begin{tabular}{lllllll}
\hline Questionnaire material group & 1 & 2 & 3 & 4 & 5 & 6 \\
\hline Text's number in questionnaire & Text No. 1 & Text No. 5 & Text No. 7 & Text No. 4 & Text No. 2 & Text No. 3 \\
& Text No. 11 & Text No.6 & Text No. 9 & Text No. 12 & Text No. 8 & Text No. 14 \\
& Text No. 19 & Text No. 16 & Text No. 10 & Text No. 17 & Text No. 13 & Text No. 15 \\
& & & & & & Text No. 18 \\
\hline
\end{tabular}


Table 4 Age profile of respondent

\begin{tabular}{lll}
\hline Age range (years) & Number in respondent & $\begin{array}{l}\text { Percentage of } \\
\text { respondent } \\
(\%)\end{array}$ \\
\hline $15-20$ & 426 & 55.2 \\
$21-25$ & 302 & 39.1 \\
$26-30$ & 22 & 2.8 \\
$31-35$ & 18 & 2.3 \\
\hline
\end{tabular}

Table 5 Educational background of respondent

\begin{tabular}{lcl}
\hline Major & Number in respondent & $\begin{array}{l}\text { Percentage of } \\
\text { respondent } \\
(\%)\end{array}$ \\
\hline Education & 255 & 33.0 \\
Economics & 166 & 21.5 \\
Engineering & 141 & 18.3 \\
Science & 95 & 12.3 \\
Social & 66 & 8.5 \\
Psychology & 32 & 4.1 \\
Medical & 7 & 0.9 \\
Art & 6 & 0.8 \\
\hline
\end{tabular}

questionnaire in the duration range from 45 until $60 \mathrm{~min}$. To comply with proper human research ethics, the lecturers informed the respondents about the nature of the research and the academic purpose of the survey. The respondents were also ensured about their confidentiality of their replies. Moreover, since the lecturers were present in the classroom during respondents taking questionnaire, they also provided detailed explanation to the respondents regarding the items of the questionnaire to assure the respondents understand each item properly.

\section{Results and discussion}

The survey explored respondent's opinion regarding six parameters of the written online information on biomass technology following the work of Harvey and Fleming [20, 21]. They are (1) attitudes toward amount of text of each online information, (2) perceived ease to follow the written online biomass technology information, (3) attitudes toward difficulty of word and phrases chosen to construct the biomass technology online information, (4) opinions on whether more common words 1 ind phrases would make the text easier to understand, (5) opinions on general comprehension of the text by others, and (6) perceived use of the text in explaining biomass energy technology. However, due to the limitation of available space in the journal, only parameters (1)-(4) of the survey's results were reported with percentages of frequencies for each response, as shown in Tables 6 and 7.

Respondents were asked to indicate whether each written online information on biomass energy technology contain too little text, enough text, or too much text. As shown in Table 6a, the majority of respondents (more than 50\%) indicated that Text Nos. 1, 10, and 17 are considered as too long. The texts consist of more than 900 words; however, only Text No. 5, whose 1011 words were not indicated by majority of respondents as too long. Only $40.7 \%$ of respondents considered Text No. 5 is too long. None of the texts are considered as too little by majority of the respondents; however, some text materials are indicated as having enough texts by majority of respondents (more than $80 \%$ ). Those are Text Nos. 15,16 , and 19 which consist of 400-480 words.

Respondents were also asked to indicate how easy to follow the written online information on biomass energy technology. Perceived ease to follow the texts was addressed using four levels of Likert-type scale from very easy to very difficult, and the frequency of results is shown in Table $6 \mathrm{~b}$. The majority of respondents indicated almost all the texts are easy (level 2) and very easy (level 1 of the scale) to follow. Only Text No. 1 is indicated as difficult (level 3) to follow by nearly majority $(39.4 \%)$ of respondents. The text is created and published by publisher category of university, and the text is also the longest text material among the others. On the contrary, Text No. 11 is indicated as very easy (level 1) and easy (level 2) by almost all respondents (47.7 and $44.5 \%$, respectively). Quite a few respondents consider Text No. 11 as difficult (7.8\%), and moreover, this text is the only text materials with none of respondent consider it as very difficult. The text is created and published by publisher category of government body for research and development, and the text is also the least text material among the others. This respondents' choice reflects the nature of people in reacting toward long text as it is expected to be difficult to follow. We tend to be lazy when we are shown a long text and asked to read it. It is suddenly presumed that the text is difficult to follow although we have not read it yet completely. Given the nature of longer text compared with the shorter one that the longer tends to describe more and to include many information in it, which consequently may overburden the reader of the text. On the contrary, the nature of shorter texts tends to describe less information which in turn, only to include more general, and consequently less specific, information into the text due to limited explaining words.

Respondents were also asked to indicate whether the words and phrases in the text are easy or difficult to understand; otherwise, the words and phrases are understandable with some difficulty. As shown in Table 7a, none of 
Table 6 Respondents' attitudes toward amount of text of each online information (a) and their perceived ease to follow the online information (b)

\begin{tabular}{|c|c|c|c|c|c|c|c|}
\hline \multirow{2}{*}{$\begin{array}{l}\text { Text's designated } \\
\text { number }\end{array}$} & \multicolumn{3}{|l|}{ (a) } & \multicolumn{4}{|l|}{ (b) } \\
\hline & Too little (\%) & Enough (\%) & Too much (\%) & Very easy $(\%)$ & Easy (\%) & Difficult (\%) & $\begin{array}{l}\text { Very } \\
\text { difficult } \\
(\%)\end{array}$ \\
\hline Text No. 1 & 0.8 & 43.3 & 55.9 & 10.2 & 41.7 & 39.4 & 8.7 \\
\hline Text No. 2 & 8.4 & 79.8 & 11.8 & 31.1 & 49.6 & 16.0 & 3.4 \\
\hline Text No. 3 & 5.3 & 50.8 & 43.9 & 14.4 & 50.0 & 25.8 & 9.8 \\
\hline Text No. 4 & 14.0 & 75.2 & 10.7 & 28.9 & 57.0 & 10.7 & 3.3 \\
\hline Text No. 5 & 2.4 & 56.9 & 40.7 & 23.6 & 43.1 & 23.6 & 9.8 \\
\hline Text No. 6 & 37.9 & 54.8 & 7.3 & 43.5 & 39.5 & 13.7 & 3.2 \\
\hline Text No. 7 & 2.4 & 78.2 & 19.4 & 28.2 & 50.0 & 17.7 & 4.0 \\
\hline Text No. 8 & 0.8 & 64.5 & 34.7 & 14.9 & 40.5 & 37.2 & 7.4 \\
\hline Text No. 9 & 16.9 & 74.2 & 8.9 & 25.0 & 45.2 & 25.0 & 4.8 \\
\hline Text No. 10 & 5.0 & 26.7 & 68.3 & 20.0 & 36.7 & 29.2 & 14.2 \\
\hline Text No. 11 & 26.6 & 69.5 & 3.9 & 47.7 & 44.5 & 7.8 & 0 \\
\hline Text No. 12 & 4.1 & 57.0 & 38.8 & 24.0 & 44.6 & 24.8 & 6.6 \\
\hline Text No. 13 & 5.0 & 47.5 & 47.5 & 20.8 & 43.8 & 24.2 & 11.7 \\
\hline Text No. 14 & 7.1 & 66.1 & 26.8 & 15.7 & 51.2 & 26.8 & 6.3 \\
\hline Text No. 15 & 7.2 & 80.8 & 12.0 & 24.0 & 46.4 & 24.8 & 4.8 \\
\hline Text No. 16 & 4.8 & 86.4 & 8.8 & 35.2 & 42.4 & 17.6 & 4.8 \\
\hline Text No. 17 & 1.7 & 27.8 & 70.4 & 13.9 & 41.7 & 27.8 & 16.5 \\
\hline Text No. 18 & 12.2 & 70.7 & 17.1 & 20.3 & 42.3 & 30.1 & 7.3 \\
\hline Text No. 19 & 6.9 & 82.3 & 10.8 & 21.5 & 55.4 & 21.5 & 1.5 \\
\hline
\end{tabular}

the texts are indicated as difficult to understand by majority of respondents. The highest percentage of the texts whose words and phrases are considered by respondents as difficult to understand are Text Nos. 10, 13, and 17. The texts are created and published by publisher category of community and those are also categorized as long text materials among the others. Although those texts (Nos. 10, 13, and 17) are created by three different community groups, but all of them are considered as the scientists or science-based groups.

This result confirms a common stereotype of engineers and scientists who are perceived as having poor communication skills [44]. Communication of engineers and scientist usually happened between peer scientists and engineers by means of academic or scientific conference and meeting, peer-reviewed academic papers, or technical training. The actors of that communication type usually have relatively similar knowledge base in comparison with that of lay person communication.

More than a half of text materials whose words and phrases are considered by majority of respondents (more than $50 \%$ ) as easy to understand are also categorized as short text materials among the others. Considering the aforementioned nature of longer text compared with the shorter one that the longer tends to describe more and to include many information in it, which probably contain more specific and technical terms as they are common in the information related to science and technology. Those terms might be found difficult to understand by respondents. Since the nature of shorter texts tends to be otherwise than that of the longer ones, more general, and consequently less specific and less technical, terms contained therein could also be easier to understand by respondents.

Still in relation with previous parameter regarding words and phrases, majority of respondents (more than 55\%) suggested that more common words and phrases would make the texts easier to understand as shown in Table $7 \mathrm{~b}$. Only for Text Nos. 2 and 11, majority of respondents (53.8 and $54.7 \%$ respectively) suggested otherwise. Since almost none of respondents suggested that words and phrases of Text Nos. 2 and 11 are difficult to understand, as shown in Table 7a, majority of respondents did not suggest that more common words and phrases would make Text Nos. 2 and 11 easier to understand as shown in Table $7 \mathrm{~b}$.

\section{Conclusions and recommendations}

This study aimed to indicate the need of improvement in preparation of written information on biomass energy as 
Table 7 Respondents' attitudes toward difficulty of words and phrases used by the online information (a) and their opinions on whether more common words and phrases would make the text easier to understand (b)

\begin{tabular}{|c|c|c|c|c|c|}
\hline \multirow{2}{*}{$\begin{array}{l}\text { Text's designated } \\
\text { number }\end{array}$} & \multicolumn{3}{|l|}{ (a) } & \multicolumn{2}{|l|}{ (b) } \\
\hline & $\begin{array}{l}\text { Easy to under- } \\
\text { stand }(\%)\end{array}$ & $\begin{array}{l}\text { Could understand with } \\
\text { some difficulty (\%) }\end{array}$ & $\begin{array}{l}\text { Difficult to under- } \\
\text { stand }(\%)\end{array}$ & $\begin{array}{l}\text { Held view: yes, easier to } \\
\text { understand }(\%)\end{array}$ & $\begin{array}{l}\text { Held view: no, not } \\
\text { easier to understand } \\
\text { (\%) }\end{array}$ \\
\hline Text No. 1 & 18.1 & 75.6 & 6.3 & 76.4 & 23.6 \\
\hline Text No. 2 & 53.8 & 46.2 & 0 & 46.2 & 53.8 \\
\hline Text No. 3 & 33.3 & 61.4 & 5.3 & 59.1 & 40.9 \\
\hline Text No. 4 & 52.9 & 45.5 & 1.7 & 56.2 & 43.8 \\
\hline Text No. 5 & 39.8 & 57.7 & 2.4 & 71.5 & 28.5 \\
\hline Text No. 6 & 62.1 & 36.3 & 1.6 & 59.7 & 40.3 \\
\hline Text No. 7 & 52.4 & 44.4 & 3.2 & 58.1 & 41.9 \\
\hline Text No. 8 & 27.3 & 65.3 & 7.4 & 70.2 & 29.8 \\
\hline Text No. 9 & 29.8 & 63.7 & 6.5 & 71.8 & 28.2 \\
\hline Text No. 10 & 35.8 & 51.7 & 12.5 & 65.8 & 34.2 \\
\hline Text No. 11 & 68.0 & 31.3 & 0.8 & 45.3 & 54.7 \\
\hline Text No. 12 & 41.3 & 52.9 & 5.8 & 55.4 & 44.6 \\
\hline Text No. 13 & 38.3 & 48.3 & 13.3 & 56.7 & 43.3 \\
\hline Text No. 14 & 32.3 & 60.6 & 7.1 & 67.7 & 32.3 \\
\hline Text No. 15 & 40.0 & 56.8 & 3.2 & 62.4 & 37.6 \\
\hline Text No. 16 & 53.6 & 44.0 & 2.4 & 60.0 & 40.0 \\
\hline Text No 17 & 31.3 & 55.7 & 13.0 & 64.3 & 35.7 \\
\hline Text No. 18 & 36.6 & 54.5 & 8.9 & 61.8 & 38.2 \\
\hline Text No. 19 & 50.8 & 46.9 & 2.3 & 58.5 & 41.5 \\
\hline
\end{tabular}

supportive effort to raise people concern on waste recycle and renewable energy in general. Besides focusing on content as the common practice of information preparation, we also need to consider whether the information is friendly to public's reading ability. As a common practice in dissemination of waste recycle and renewable energy information so far, scientist and engineer mostly spend most of the preparation effort to the content of information only. This study suggests them to pay more attention on the readability factor in preparation of written information on biomass energy in regard to promotion of waste recycling. Furthermore, as Harvey and Fleming concluded on the rapid appraisal method as easily administered method [22], the adoption of the method on waste recycle and renewable energy in general may also encourage more active involvement of scientist and engineer in the promotion of waste recycling, although they are not specialists in linguistics and perceived as having poor communication skills. The concern on readability concept by scientists and engineers of waste recycle technology and biomass energy technology would not only attract them to engage more with public as an important factor to the successful implementation of those technologies, but also to make those scientists and engineers as public campaigners, although less specialized, on the issues of waste recycle and biomass energy. It may also accelerate successful adoption of the technologies into society.

Acknowledgements Financial support for this study was provided by Japan Society for the Promotion of Science (JSPS) KAKENHI Grant Number $15 \mathrm{H} 05228$. The authors greatly appreciate the support. The authors also thank Mr. Martino Wibowo of Gici School of Economics, Mr. Muhammad Yasir Zain of Universitas Madura, and Mr. Efendi of Universitas Bangka Belitung for the tireless assistance during the extensive work of this survey. The authors are also grateful to all those who agreed to read the texts and answering the questionnaire.

\section{References}

1. Zhang DQ, Tan SK, Gersberg RM (2010) Municipal solid waste management in China: status, problems and challenges. J Environ Manag 91: 1623-1633. doi:10.1016/j.jenvman.2010.03.012

2. Novianti S, Biddinika MK, Prawisudha P, Yoshikawa K (2014) Upgrading of palm oil empty fruit bunch employing hydrothermal treatment in lab-scale and pilot scale. Proc Environ Sci 20:46-54. doi:10.1016/j.proenv.2014.03.008

3. Aziz M, Prawisudha P, Prabowo B, Budiman BA (2015) Integration of energy-efficient empty fruit bunch drying with gasification/combined cycle systems. Appl Energy 139:188-195. doi:10.1016/j.apenergy.2014.11.038 
4. Prabowo B, Susanto H, Umeki K et al (2015) Pilot scale autothermal gasification of coconut shell with $\mathrm{CO}_{2}-\mathrm{O}_{2}$ mixture. Front Energy 9:362-370. doi:10.1007/s1 1708-015-0375-5

5. Syamsiro M, Saptoadi H, Tambunan BH (2011) Experimental investigation on combustion of bio-pellets from Indonesian cocoa pod husk. Asian J Appl Sci 4:712-719. doi:10.3923/ ajaps.2011.712.719

6. Syamsiro M, Saptoadi H, Tambunan BH, Pambudi NA (2012) A preliminary study on use of cocoa pod husk as a renewable source of energy in Indonesia. Energy Sustain Dev 16:74-77. doi: 10.1016/j.esd.2011.10.005

7. Pambudi NA, Torii S, Saptoadi H et al (2010) Experimental study on combustion of biobriquettes Jatropha curcas solid waste. J Environ Eng Manag 20:133-136

8. Sterner T, Bartelings H (1999) Household waste management in a Swedish municipality: determinants of waste disposal, recycling and composting. Environ Resour Econ 13:473-491

9. Agunwamba J (1998) Solid waste management in Nigeria: problems and issues. Environ Manag 22:849-856. doi:10.1007/ s002679900152

10. Desta H, Worku H, Fetene A (2014) Assessment of the Contemporary municipal solid waste management in urban environment: the case of Addis Ababa, Ethiopia. J Environ Sci Technol 7:107122. doi:10.3923/jest.2014.107.122

11. Hasan MH, Mahlia TMI, Nur H (2012) A review on energy scenario and sustainable energy in Indonesia. Renew Sustain Energy Rev 16:2316-2328. doi:10.1016/j.rser.2011.12.007

12. Abu Bakar AS, Ameer R (2011) Readability of Corporate Social Responsibility communication in Malaysia. Corp Soc Responsib Environ Manag 18:50-60. doi: $10.1002 / \mathrm{csr} .240$

13. Lim X Le, Lam WH (2014) Public acceptance of marine renewable energy in Malaysia. Energy Policy 65:16-26. doi:10.1016/j. enpol.2013.09.053

14. Luthra S, Kumar S, Garg D, Haleem A (2015) Barriers to renewable/sustainable energy technologies adoption: Indian perspective. Renew Sustain Energy Rev 41:762-776. doi:10.1016/j. rser.2014.08.077

15. UNDP United Nations Population Division. Department of Economic and Social Affairs. http://www.un.org/en/development/ desa/population/. Accessed 5 May 2016

16. World Bank Indonesia. Data. http://data.worldbank.org/country/ indonesia. Accessed 5 May 2016

17. Insight M (2012) From MarkPlus Insight's Indonesia Internet Users Survey 2012 Waizly Darwin Chief Operations, Marketeers @ Marketeers Club Dinner Seminar Nov 2012

18. DuBay W (2004) The principles of readability. Costa Mesa Impact Inf. doi: 10.1.1.91.4042

19. Singer H, Donlan D (1982) Active comprehension: problemsolving schema with question generation for comprehension of complex short stories. Read Res Q 17:166-186.

20. Harvey HD, Fleming P (2003) The readability and audience acceptance of printed health promotion materials used by environmental health departments. J Environ Health 65:22-28

21. Harvey HD, Fleming P, Cregan K, Latimer E (2000) The health promotion implications of the knowledge and attitude of employees in relation to health and safety leaflets. Int J Environ Health Res 10:315-329. doi:10.1080/0960312002001519

22. Harvey HD, Fleming P (2000) A rapid appraisal method for the selection and pre-testing of environmental health leaflets. J R Soc Promot. Health (London) 120:112-116

23. Biddinika MK, Lestari RP, Indrawan B, et al (2016) Measuring the readability of Indonesian biomass websites: The ease of understanding biomass energy information on websites in the
Indonesian language. Renew Sustain Energy Rev 59:1349-1357. doi:10.1016/j.rser.2016.01.078

24. Bab III Energi Biomassa. http://web.ipb.ac.id/ tepfteta/elearning/media/EnergidanListrikPertanian/MATERIWEBELP/BabIII BIOMASSA/indexBIOMASSA.htm. Accessed 9 Oct 2014

25. Apa itu Energi Biomassa? Definisi dan 4 Contohnya. http:// www.amazine.co/27020/apa-itu-energi-biomassa-definisi-dan4-contohnya/. Accessed 15 Oct 2014

26. Pengetahuan Dasar tentang Biomassa. http://wiki.openthinklabs. com/science-corner/pengenalan-energi-untuk-anak/sumber-sumber-energi/terbarukan/pengetahuan-dasar-tentang-bio. Accessed 10 Oct 2014

27. Biomassa sebagai sumber energi terbarukan. http://www. dw.de/biomassa-sebagai-sumber-energi-terbarukan/a-3057079. Accessed 14 Oct 2014

28. Berkenalan dengan Energi Biomassa. http://www.anneahira. com/energi-biomassa-kemurgi.htm. Accessed 13 Oct 2014

29. Pengertian biomassa. http://www.indoenergi.com/2012/04/ pengertian-biomassa.html. Accessed 9 Oct 2014

30. Energi Biomassa dari Limbah Organik. http://www.indoenergi.com/2012/04/energi-biomassa-dari-limbah-organik.html. Accessed 15 Oct 2014

31. Biomassa untuk potensi energi terbarukan Indonesia. http:// iccc-network.net/id/lib/article/leds/270-biomassa-untuk-potensienergi-terbarukan-indonesia. Accessed 10 Oct 2016

32. Biomassa. http://www.p3tkebt.esdm.go.id/index. php?option $=$ com_content\&view $=$ article $\& i d=369 \&$ Itemid $=491$ \&lang=en. Accessed 14 Oct 2014

33. Energi alternatif itu bernama biomassa. http://netsains. net/2008/03/energi-alternatif-itu-bernama-biomassa/. Accessed 13 Oct 2014

34. Biogas. http://b2te.bppt.go.id/index.php/hasil-riset/98-hasilriset-b2te/93-biogas.html. Accessed 9 Oct 2016

35. Biomassa sebagai alternatif energi. http://wwwimago, or.id/2013/04/biomassa-sebagai-alternatif-energi.html. Accessed 15 Oct 2014

36. Pemanfaatan limbah biomassa cangkang kakao sebagai sumber energi terbarukan. http://beranda.miti.or.id/pemanfaatan-limbahbiomassa-cangkang-kakao-sebagai-sumber-energi-terbarukan/. Accessed 10 Oct 2014

37. Syamsiro M (2013) Teknologi Gasifikasi Biomassa untuk Kebutuhan Energi di Pesantren. http://www.nu.or.id/a,publicm,dinamic-s,detail-ids, 14-id,47199-lang,id-c,teknologi-t,Tekno logi+Gasifikasi+Biomassa+untuk+Kebutuhan+Energi+di+Pe santren-.phpx. Accessed 14 Oct 2014

38. Energi terbarukan. http://id.wikipedia.org/wiki/Energi_terbarukan. Accessed 13 Oct 2014

39. Keuntungan energi biomassa. http://wwwindoenergi. com/2012/04/keuntungan-energi-biomassa.html. Accessed 9 Oct 2014

40. Energi biomassa, energi terbarukan yang merakyat. http://www. kamase.org/?p=1113. Accessed 15 Oct 2014

41. Energi terbarukan. http://www.sky-energy.co.id/renewableenergy-2/. Accessed 10 Oct 2014

42. Pengertian biomassa. http://budisma.web.id/pengertian-biomassa/. Accessed 13 Oct 2014

43. Biddinika MK, Indrawan B, Yoshikawa K, et al (2014) Renewable energy on the internet: the readability of Indonesian biomass websites. Energy Proc 61:1376-1379. doi:10.1016/j. egypro.2014.12.131

44. Hankins N (2002) Communication skills for engineers and scientists. Process Saf Environ 80:282. doi: $10.1205 / 095758202762277650$ 
HASIL CEK_Survey on readability of online information for upgrading understandability of biomass energy technology

ORIGINALITY REPORT

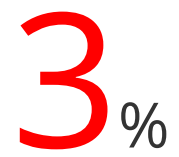

SIMILARITY INDEX

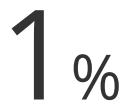

INTERNET SOURCES

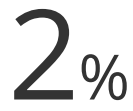

PUBLICATIONS
$1 \%$

STUDENT PAPERS

1 Harold D. Harvey, Paul Fleming, Karen Cregan, Emily Latimer. "The health promotion implications of the knowledge and attitude of employees in relation to health and safety leaflets", International Journal of Environmental Health Research, 2000 Publication

2 Submitted to Syiah Kuala University Student Paper 